\title{
PERMAINAN EDUKASI (GAME) SEBAGAI STRATEGI PENDIDIKAN KARAKTER
}

\author{
Andika Aprilianto \\ Institut Pesantren KH Abdul Chalim Pcaet Mojokerto \\ Andika4ikhac@gmail.com \\ Wahyuni Mariana \\ Institut Pesantren KH. Abdul Chalim Pacet Mojokerto \\ rwahyuni61@gmail.com
}

\begin{abstract}
Abstrak
Game Sebagai Strategi Pendidikan Karakter. Dimasa sekarang ini pendidikan karakter sangatlah penting ditanamkan kepada anak sejak dini. Kehidupan modern dengan aktifitas sosialnya yang makin beragam dikhawatirkan bisa merubah dan mempengarubi karakter anak. Penanaman karakter ini bisa dimulai dari lingkungan terkecil dan terdekat mereka yaitu keluarga. Selanjutnya bisa dikembangkan lagi di lingkungan pendidikan sekolah dan lingkungan masyarakat disekitar mereka. Penanaman karakter pada anak tidak hanya dilakukan lewat pemberian materi-materi pembelajaran di sekolah ataupun pembiasaanpembiasaan saja. Tapi juga bisa dilakukan melalui kegiatan yang menyenangkan yaitu bermain. Bermain ini bisa menggunakan permainan yang bersifat edukatif menggunakan media dan ataupun tanpa menggunakan media. Melalui pemainan-permainan edukatif tersebut diharapkan mampu menanamkan karakter-karakter yang baik kepada anak.
\end{abstract}

Kata kunci: Game, Pendidikan Karakter. Strategy Pendidikan

\section{Abstract}

Game as a Character Education Strategy. Today, character education is very important to be instilled in children from an early age. Modern life with increasingly diverse social activities is feared to change and influence the character of children. This character planting can be started from the smallest

Nazhruna: Jurnal Pendidikan Islam

Vol. 1 No 1 Maret 2018. Issn: 2614-8013. Hal. 139-158 
and closest environment, the family. Furthermore, it can be further developed in the school education environment and the surrounding community. Character building in children is not only done through the provision of learning materials in school or habituation. But it can also be done through fun activities, namely playing. This play can use games that are educational using media and or without using media. Through educational games it is expected to be able to instill good characters to children.

Keyword: Game, Character Education, Education of Strategy.

\section{Pendahuluan}

Masa kanak-kanak adalah masa dimana seorang anak masih suka dengan hal yang menyenangkan seperti bermain. Anak dan bermain adalah sebuah kesatuan yang tidak bisa dipisahkan. Seorang anak tidak lepas dari yang namanya dunia bermain ketika mulai dia lahir hingga mencapai usia sebelum memasuki masa remaja. Pada masa itu anakanak cenderung menuangkan berbagai imajinasinya melalui sebuah alat permainan dalam kegiatan bermain mereka. Pada zaman saat ini, beragam permainan banyak ditawarkan oleh produsen mainan. Mulai dari permainan konvensional yang banyak kita temukan di jual bebas di toko mainan hingga permaianan berbasis computer atau aplikasi. Dari beragam mainan tersebut selain menawarkan nilai entertain atau hiburannya tapi juga tidak sedikit permainan yang didalamnya menawarkan nilai edukasi atau pendidikannya.

Jika kita lihat dari sudut pandang pendidikan, seorang anak bisa mempelajari segala hal melalui berbagai strategi, metode dan media pembelajaran. Karena dunia anak adalah dunia bermain, sehingga guru sering mengintegrasikan kegiatan belajar mengajar melalui sebuah aktivitas permainan ${ }^{1}$. Strategi, metode dan media pembelajaran adalah beberapa unsur pokok yang harus ada dalam suatu rencana proses pembelajaran. Rencana proses pembelajaran biasanya dibuat oleh guru pengampu mata pelajaran dengan sebaik-baiknya demi mencapai tujuan pembelajaran yang telah ditetapkan. Strategi dan metode yang digunakan oleh guru biasanya ditunjang dengan ketersediaan media

\footnotetext{
${ }^{1}$ Surya Anggraini Fina, Strategi Pembelajaran (Yogyakarta: Ladang Kata, 2017), 7.
} 
pembelajaran. Media pembelajaran tersebut biasanya memang disediakan oleh lembaga sekolah ataupun guru pengampu mata pelajaran. Tapi tidak semua lembaga sekolah bisa atau mampu menyediakan media pembelajaran yang dibutuhkan. Sekali lagi disini seorang guru benar-benar dituntut kreatifitasnya dalam menggunakan metode dan media pembelajaran. Seorang guru yang bisa menggunakan kreatifitasnya tidak dipungkiri bisa memadukan beberapa hal dalam suatu kegiatan pembelajaran, misalnya saja dengan menggunakan permainan edukatif. Melalui sebuah permainan edukatif guru diharapkan mampu menyampaikan materi pembelajaran secara efektif, efisien dan tentunya menyenangkan sehingga tujuan pembelajaran juga bisa tercapai secara maksimal.

\section{Pembahasan}

\section{Game/Permainan Edukasi}

Game atau permainan adalah sesuatu yang dapat dimainkan dengan aturan tertentu sehingga ada yang menang dan ada yang kalah, biasanya dalam konteks tidak serius dengan tujuan refreshing. Ada beberapa orang yang masih merasa bisa bila mendengar kata "permainan", mereka lebih sering mengenal dan memahami kata "bermain" dan "mainan". Padahal secara arti, ketiga kata tersebut memiliki arti yang berbeda. Secara sederhana dapat diartikan seperti ini, "bermain" adalah suatu kegiatan main, "mainan" adalah suatu yang digunakan untuk main dan sedangkan "permainan" adalah kegiatan yang berisi bermain dan mainan ${ }^{2}$. Jadi, dapat dikatakan bahwa ketiga kata tersebut yaitu, "bermain, mainan dan permainan" adalah kata yang mempunyai perbedaan dari segi maknanya, tapi ketiga kata tersebut mempunyai keterkaitan antara satu dengan lainnya.

Sebuah kegiatan bermain adalah suatu dunia bagi anak-anak. Anak dan bermain adalah suatu hal yang tidak akan pernah terpisahkan. Pada saat ini sebuah kegiatan bermain tidaklah harus dengan menggunakan suatu kegiatan atau aktifitas fisik saja, tapi juga sudah didukung dengan adanya perkembangan teknologi yang ada. Pada zaman dahulu, suatu permainan tradisional (permainan rakyat) biasa dimainkan oleh anak-anak secara berkelompok di halaman rumah

\footnotetext{
${ }^{2}$ Fina, 8 .
} 
mereka yang masih luas. Seluruh anak baik laki-laki atau perempuan akan berkumpul dan bermain bersama. Alat yang mereka gunakan pada saat bermain biasanya alat-alat yang mudah mereka jumpai disekitar mereka. Mereka menggunakan lagu-lagu daerah atau lagu anak-anak sebagai pengiring dalam permainan mereka.

Sekarang, permainan tradisional sudahlah sedikit tergeser dengan adanya permianan-permainan baru yang lebih beragam dan lebih modern. Hal tersebut tidaklah terlepas dari salah satu fenomena yang terjadi saat ini yaitu Globalisasi. Globalisasi adalah proses integrasi Internasional yang terjadi karena pertukaran pandangan dunia, produk, pemikiran, dan aspek-aspek kebudayaan lainnya. Kemajuan infrastruktur, transportasi dan alat telekomunikasi, termasuk kemunculan internet, merupakan faktor utama dalpam globalisasi yang semakin mendorong saling ketergantungan aktivitas ekonomi dan budaya (Wikipedia. Akses. 2018). Pengaruh Globalisasi tidaklah terjadi pada hal-hal yang kompleks seperti ekonomi, teknologi ataupun masalah infrastrukturnya saja, tapi hal tersebut juga mempengaruhi pada budaya suatu masyarakat itu sendiri. Masyarakat disini juga bukanlah masyarakat yang tinggal di negara yang maju dan hidup dengan berbagai kemajuan teknologinya saja, tapi juga masyarakat yang hidup di negara berkembang dan tidak menutup kemungkinan masyarakat yang hidup di negara terbelakang juga mengalami dampak atau pengaruh dari apa yang namanya Globalisasi. Meskipun Globalisasi pengaruhnya tidak secepat pada negara maju, tapi Globalisasi tetaplah akan memberikan suatu dampak kepada masyarakat di suatu negara berkembang ataupun negara yang belum berkembang.

Budaya adalah salah satu hal yang bisa terpengaruh akan adanya Globalisasi. Menurut Kamus Besar Bahasa Indonesia, budaya adalah suatu pikiran, akal budi atau adat istiadat (Kbbi. Web Id). Jadi, dappat kita ketahui budaya adalah suatu hasil pikiran/akal budi dari suatu masyarakat yang nantinya pikiran tersebut akan menjadi suatu adat istiadat. Jika suatu arus Globalisasi dapat mempengaruhi keberlangsungan suatu budaya, tentunya hal tersebut sangatlah 
dikhawatirkan jika budaya tersebut nantinya akan punah keberadaanya. Apalagi jika hal tersebut terjadi pada negara yang sedang berkembang. Negara Indonesia sebagai salah satu negara berkembang saat ini juga tengah mengalami dampak dari Globalisai terhadap kekayaan budayanya. Paling mudah kita temui adalah pada salah satu hasil budayanya yaitu permainan tradisionalnya.

Dikutip dari salah satu penulis berita di surat majalah online, Bagus K. Anand mengatakan bahwa, Globalisasi telah melunturkan warisan-warisan budaya suatu bangsa, tidak terkecuali budaya-budaya yang ada di negara kita Indonesia. Salah satu warisan budaya yang sedikit demi sedikit luntur tersebut adalah budaya permaian tradisionalnya. Permainan tradisional Indonesia merupakan suatu warisan budaya asli Indonesia dan juga kekayaan budaya Indonesia. Permainan tradisional saat ini telah tergantikan dengan adanya teknologi computer, internet dan seterusnya. Bahkan bisa dihitung hanya ada berapa anak-anak yang masih memainkan permainanpermainan tradisional. Meskipun permainan tradisional mengajarkan tentang kebersamaan, kekompakan, gotong royong, tapi kemajuan teknologi telah mempengaruhi pola pikir anak-anak pada zaman sekarang ini. Salah satu pola pikir yang paling mudah ditemui adalah pola pikir individualis (Kompas: 2018).

Permainan tradisional maupun permainan modern memanglah banyak sekali pengaruhnya terhadap pola pikir anak. Di satu sisi permainan tradisional mengajarkan anak untuk tidak individualis. Tapi di sisi lain jika anak tidak dikenalkan dengan suatu kemajuan teknologi, mereka juga tidak bisa mengikuti perkembangan zaman. Sebagai orang tua ataupun guru haruslah mereka sebisa mungkin mengenalkan teknologi tanpa harus meninggalkan suatu budaya yang ada. Seimbang adalah kunci utamanya yang harus dilakukan orang tua maupun guru dalpam rangkpa mengenalkan teknologi tanpa meninggalkan suatu budaya yang ada yang haruslah dijaga oleh anak-anak sebagai penerus generasi yang akan datang. 


\section{Strategi Pembelajaran}

Strategi pembelajaran adalah suatu cara yang dilakukan oleh guru dalam menyampaikan materi pelajaran kepada siswanya. Suatu strategi pembelajaran diberikan biasanya untuk memudahkan guru maupun siswa dalam menyampaikan dan menerima suatu materi pelajaran. Strategi pembelajaran berguna untuk menunjang proses belajar mengajar, strategi pembelajaran dimaksudkan untuk siswa agar lebih mengerti atau memahami suatu materi pelajaran yang diajarkan. Selain itu, strategi pembelajaran juga berguna bagi guru agar dapat memberikan apa yang dibutuhkan seorang siswa. Dengan adanya strategi pembelajaran akan lebih mudah dalam mencapaikan sebuah tujuan pembelajaran yang diinginkan dan yang telah dirumuskan sebelumnya.

Pada saat ini berbagai strategi pembelajaran telah dibuat secara beragam dan setiap strategi pembelajaran tersebut mempunyai ciri khas masing-masing. Salah satu contohnya yaitu strategi pembelajaran kontekstual atau biasanya juga disebut dengan Contextual Teaching and Learning (CTL). Strategi pembelajaran tersebut mengaitkan materi yang diajarkan dengan situasi dunia nyata (kehidupan) siswa. Sehingga hasil pembelajaran yang diperoleh siswa akan lebih bermakna ${ }^{3}$. Ciri khusus yang paling mudah dikenali dari pembelajaran kontekstual ini adalah dari lima prinsipinya: Konstruktivisme (constructivism), bertanya (questioning), menemukan (inquiry), masyarakat belajar (learning community), pemodelan (modeling), refleksi (reflection) dan penilaian sebenarnya (authentic assessment) ${ }^{4}$. Berdasarkan ciri-ciri tersebut kita bisa mengetahui jika strategi pembelajaran kontekstual mempunyai beberapa prinsip yang sekaligus menjadi sebuah tahapan-tahapan yang dilalui oleh siswa untuk mencapai tujuan pembelajaran yang telah dirancang sebelumnya.

Jika pada paragraph sebelumnya telah disebutkan salah satu strategi pembelajaran yaitu pembelajaran Kontekstual, maka ada satu

\footnotetext{
${ }^{3}$ Fina, 173.

${ }^{4}$ Fina, 185.
} 
lagi strategi pembelajaran yaitu strategi pembelajaran Fun Learning (pembelajaran menyenangkan). Dalam konteksnya, maksud dari pembelajaran menyenangkan tersebut adalah siswa akan lebih banyak diarahkan untuk memiliki motivasi belajar yang lebih tinggi dengan penciptaan situasi yang menyenangkan dan menggembirakan bagi mereka ${ }^{5}$. Secara umum, suatu kegiatan bermain adalah sebuah kegiatan yang dimaknai sebagai suatu kegiatan belajar yang dengan sengaja direncanakan dalam rangka menyampaikan tujuan pembelajaran melalui sebuah strategi yang menyenangkan. Kegiatan pembelajaran tersebut umumnya dilakukan pada pembelajaran anak usia dini maupun anak Sekolah Dasar pada kelas bawah. Kurikulum yang digunakan dalam kegiatan pembelajaran semacam itu biasanya mempunyai ciri khusus yang termuat didalamnya.

Menurut NAEYC Early Childhood Program Standard ada dua hal penting yang termuat dalam kurikulum pembelajaran anak usia dini atau anak kelas bawah pada Sekolah Dasar, yaitu: (1) Program kegiatan bermain pada anak usia dini penetapan kurikulumnya berpusat pada anak dan dapat mendukung kegiatan pembelajaran dan pekembangan pada setiap aspek baik estetika, kognitif, emosional, bahasa, fisik dan sosial, (2) Kurikulum berorientasi pada hasil dan dikaitkan dengan berbagai konsep serta pekembangan. Ketika disampaikan oleh guru pada setiap individu siswa, kurikulum yang telah dirancang tersebut dapat membantu guru dalam menyediakan pengalaman yang mengembangkan perkembangan anak ke arah yang lebih tinggi (Yuliani dan Sujiono: 2010, 17). Kurikulum pada program kegiatan bermain pengembangannya dilakukan secara konkret. Rancangan kurikulum tersebut berisi pengalaman belajar melalui bermain yang diberikan kepada siswa berdasarkan potensi dan tugas yang harus dikuasainya dalam rangka pencapaian kompetensi yang harus dicapai dan dimiliki oleh anak.

Secara umum, sebenarnya tidak ada perbedaan antara strategi pembelajaran yang lain dengan strategi pembelajaran Fun Learning. Hanya saja kurikulum yang diterapkan pada pembelajaran Fun Learning

${ }^{5}$ Zulvia Trinova, 'Hakikat Belajar Dan Bermain Menyenangkan Bagi Peserta Didik', Al-Ta Lim Journal 19, no. 3 (2012): 209. 
lebih banyak menggunakan aktivitas-aktivitas yang menyenangkan bagi para siswa. Aktivitas-aktivitas tersebut biasanya dikemas dalam sebuah game atau permainan yang banyak melibatkan partisipasi dari siswa. Game atau permainan yang digunakan dalam strategi Fun Learning biasanya permainan-permainan tentunya yang bersifat edukatif dan bertujuan mengembangkan karakter-karakter baik pada siswa. Tetapi bukan berarti game atau permainan edukatif hanya bisa dilakukan dalam sebuah starategi Fun Learning. Bisa juga game atau permainan edukatif tersebut dimasukkan dalam strategi-strategi pembelajaran yang lain. Selama guru pengampu mata pelajaran bisa mengolah antara game dengan materi pembelajaran yang diajarkan. Sehingga nanti pembelajaran dengan menggunakan game bisa dilakukan dan materi pembelajaran bisa tersampaikan sehingga tujuan pembelajaran yang direncanakan bisa tercapai.

\section{Pendidikan Karakter}

Sebelum membahas lebih jauh tentang pendidikan karakter, maka perlu diketahui sejarah tentang pendidikan karakter itu sendiri. Istilah karakter digunakan dalam dunia pendidikan dimulai sejak sekitar akhir abad 18-an. Pendidikan karakter mengajarkan dan membiasakan anak untuk mengetahui kebaikan, mencintai kebaikan dan mau melakukan kebaikan. Jadi, dengan kata lain pendidikan karakter ini memuat tentang pendidikan akhlak dan juga pendidikan moral. Akhlak atau moral yang baik contohnya seperti kreatif, kejujuran, disiplin, toleransi, kerja keras, kesabaran dan masih banyak yang lainnya. menyebutkan bahwa yang berarti pendidikan karakter adalah proses dari budaya dan sebuah kekuasaan yang bernilai luhur dalam sebuah lingkungan pendidikan, keluarga dan masyarakat. Pendidikan karakter bukanlah sekedar sebuah pendidikan yang bersifat fomalitas di sebuah lingkungan pendidikan saja. Lebih daripada itu lingkungan keluarga dan

6 Muhammad Anas Ma arif, 'Dhikr and Thinking Integration as NonDicotomic Character Education Development | Proceeding International Conference on Islamic Education (Icied)', 16 February 2018, 23-24, http://conferences.uin-malang.ac.id/index.php/icied/article/view/435. 
lingkungan masyarakat juga ikut serta dalam berperan aktif dalam memberikan sebuah pendidikan karakter ${ }^{7}$.

Pendidikan karakter juga tidak lepas dari bahasan secara religious yaitu dalam agama Islam. Dalam agama Islam, karakter biasanya diartikan dengan akhlak. Pengertian akhlak secara bahasa berasal dari bahasa Arab "khuluqun" yang artinya budi pekerti, tingkah laku, perbuatan, ataupun tabiat seorang manusia. Sedangkan menurut istilah adalah suatu pengetahuan yang didalamnya menjelaskan tentang segala hal yang baik dan buruk (benar dan salah), menentukan tujuan akhir dari usaha dan pekerjaannya, mengatur pergaulan manusia, baik pergaulan antar sesama manusia, sesama makhluk ataupun bahkan dengan Tuhannya ${ }^{8}$. Akhlak adalah suatu esensi dasar dari ajaran Islam selain aqidah dan syariah. Jadi dengan adanya akhlak akan terbina jiwa serta mental untuk menjadi manusia yang bercorak dan berhakekat tinggi kemanusiannya. Dalam Sejarah Kebudayaan Islam telah diterangkan pula bahwa Nabi Muhammad SAW diutus untuk menyempurnakan akhlaq bagi umat Islam. Salah satu hadits telah menjelaskan,

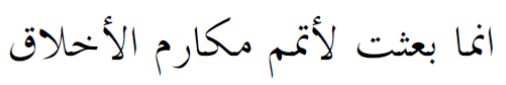

"Aku diutus di muka bumi untuk menyempurnakan akblak". (H.R. Abmad)

Dalam kitab Al-Qur'an juga Allah SW'T telah menjelaskan dalam firman-Nya,

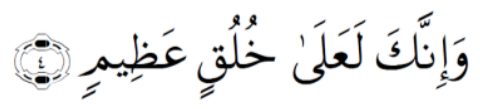

"Dan sesunggubnya engkau benar-benar, berbudi pekerti yang lubur" (Q.S AlQalam:4) (Departemen Agama RI: 2017)

7 Muhammad Anas Ma`arif, 'Analisis Strategi Pendidikan Karakter Melalui Hukuman Preventif, Ta'allum: Jurnal Pendidikan Islam 6, no. 1 (6 March 2018): 37, https://doi.org/10.21274/taalum.2018.6.1.31-56.

${ }^{8}$ Syarifah Habibah, 'Akhlak Dan Etika Dalam Islam', Jurnal Pesona Dasar 1, no. 4 (2015): 73. 
Dari hadits dan ayat tersebut telah menjelaskan bahwa betapa pentingnya posisi akhlak dalam kehidupan. Rasulullah SAW diutus oleh Allah SWT untuk menyempurnakan akhlak umat manusia yang waktu itu berada dalam masa Jahiliyah atau zaman kebodohan. Dari hal itu pula yang menyebabkan betapa pentingnya akhlak sebagai pondasi dari keimanan seseorang. Dengan akhlak atau karakter yang baik, maka orang tersebut akan selalu terdorong untuk melakukan hal yang baik pula. Sehingga kualitas iman seseorang akan menjadi semakin baik. Adapun beberapa tokoh pendidikan karakter dalam agama Islam antara lain, Imam Al-Ghazali, Ibn Maskawih, Imam Zarnuji, KH. Hasyim As `ary dan lain sebagainya ?

Pendidikan karakter di negara Indonesia sendiri dahulu lebih dikenal istilah pendidikan budi pekerti. Pendidikan budi pekerti diartikan sebagai suatu upaya yang diberikan oleh pendidik kepada peserta didik melalui sebuah latihan, pengajaran serta bimbingan. Hal tersebut dilakukan selama peserta didik mengalami proses pertumbuhan dan perkembangan terhadap dirinya. Tujuan dari pendidikan tersebut adalah sebagai bekal masa depan peserta didik agar memiliki hati nurani yang bersih, berperilaku baik dan senantiasa menjaga sikap kesusilaan dalam melaksanakan kewajiban terhadap sesama makhluk dan kepada Tuhannya. Dalam sistem perundangundangan Indonesia yaitu Undang-undang Republik Indonesia Nomor 20 Tahun 2003 tentang SISDIKNAS (Sistem Pendidikan Nasional) Bab I Pasal 1 menyatakan bahwa, Pendidikan adalah usaha sadar dan terencana untuk mewujudkan suasana belajar dan proses pembelajaran agar peserta didik secara aktif mengembangkan potensi dirinya untuk memiliki kekuatan spiritual keagamaan, pengendalian diri, kepribadian, kecerdasan, akhlak mulia, serta keterampilan yang diperlukan dirinya, masyarakat, bangsa dan negara. Sebuah proses pembelajaran di sekolah dilakukan dengan tujuan agar peserta didik selalu aktif dalam mengembangkan skill, kompetensi serta potensi dirinya. Hal tersebut

${ }^{9}$ Nixson Husin, 'Hadits-Hadits Nabi Saw. Tentang Pembinaan Akhlak', Jurnal An-Nur 4, no. 1 (2016): 15. 
juga dilakukan agar mereka memiliki control atau pengendalian diri demi mewujudkan kecerdasan baik mental maupun spiritual. Pembentukan kepribadian dengan karakter yang baik, berakhlak mulia serta juga tidak lepas dari tujuan pembelajaran di sekolah. Jika kecerdasan, kepribadian serta pengendalian diri telah terbentuk dengan baik, maka diri peserta didik akan bisa membentuk keterampilan yang diperlukan dirinya sendiri, masyarakat maupun bangsa dan negara.

Pada saat ini, Sistem pendidikan di Indonesia sendiri telah memunculkan pendidikan karakter disetiap kurikulumnya, tapi ada lebih ditekankan lagi dalam Kurikulumnya yaitu kurikulum 2013 (K13). Sistem kurikulum tersebut diusung dalam bentuk pembelajaran Tematik. Pembelajaran tematik sendiri yaitu sebuah pembelajaran yang menghimpun beberapa mata pelajaran menjadi satu tema pembelajaran. Dalam pembelajaran tematik ini, telah dimunculkan konsep pendidikan karakternya. Disetiap satu tema yang diajarkan akan selalu dimunculkan satu atau beberapa konsep pendidikan karakter. Muatan pada kurikulum 2013 mempunyai tujuan untuk mengubah siswa agar menjadi seorang yang lebih santun melalui penanaman nilai-nilai pada pendidikan karakter.

Jika kita membicarakan tentang pendidikan karakter lebih lanjut lagi, maka salah satu tokoh yang pasti sudah dikenal teorinya adalah Thomas Lickona dengan bukunya yang terkenal yaitu Educating for Character: How Our School Can Teach Respect and Responsibility Mendidik Untuk Membentuk Karakter). Menururt ${ }^{10}$ menyebutkan bahwa ada tiga bagian yang saling berhubungan dalam sebuah pendidikan karakter yaitu: pengetahuan moral, perasaan moral dan perilaku moral. Karakter yang baik terdiri dari mengetahui hal yang baik, menginginkan hal yang baik dan melakukan hal yang baik.

Suatu karakter yang baik berdasarkan paparan diatas mempunyai tiga unsur penting. Pertama. Mengetahui hal yang baik. Pengetahuan akan hal-hal yang baik sangat diperlukan oleh anak dalam awal proses pembentukan suatu karakter yang baik. Mengetahui bisa diartikan sutu proses "melihat" dari seorang anak terhadap orang

${ }^{10}$ Thomas Lickona, Educating for Character: How Our Schools Can Teach Respect and Responsibility (New York: Bantam Books, 2009), 80. 
disekitarnya. Proses tersebut paling mudah dan sedehana akan diawali dari sebuah keluarga. Sebuah keluarga menjadi tolak ukur dasar dari anak untuk membentuk karakter baiknya. Jika keluarga telah menanamkan suatu kebiasaan yang sederhana atau mencontohkan suatu kebiasaan yang sederhana kepada seorang anak, maka dapat dipastikan proses pembentukan suatu karakter dari anak tersebut bisa diawali dengan baik sebelum mereka terjun ke lingkungan yang lebih kompleks di luar lingkungan keluarga mereka. Dan juga sebaliknya, jika sebuah awal yang dimulai dari sebuah keluarga sudah tidak ditemukan suatu penanaman kebiasaan yang baik, maka sangat tidak heran jika di kedepannya anak akan cenderung belum bisa mengontrol karakter mereka sendiri ke arah yang lebih baik. Untuk selanjutnya, jika anak telah memasuki dunia sekolah, mereka tentu akan bertemu dengan orang-orang baru yang belum mereka kenal. Mulai dari temantemannya, guru atau staf lembaga sekolah bahkan tukang kebun di sekolah. Dari orang-orang tersebut seorang anak akan menemui berbagai karakter yang baru yang bahkan mungkin tidak ditemukannya di dalam keluarga mereka. Kedua. Menginginkan hal yang baik. Seorang anak jika sudah mengetahui hal-hal baik yang dia peroleh dari sekolahnya, keluarganya dan lingkungan masyaraktnya, sudah barang tentu anak tersebut akan menginginkan hal-hal baik tersebut dalam kehidupannya. Jikalau seorang anak belum mempunyai kemampuan untuk melakukan hal baik tapi setidaknya jika diawali dari mengetahui hal baik, maka selanjutnya anak tersebut akan mempunyai rasa atau keinginan akan eksistensi hal baik tersebut. Disini posisi seorang guru, keluarga dan masyarakat sekitar juga sangat dibutuhkan, sebagai suatu pendorong bagi anak untuk memunculkan rasa atau keinginan dari seorang anak dalam memunculkan hal baik. Ketiga. Melakukan hal yang baik. Mengetahui dan menginginkan hal baik akan bisa disempurnakan dengan melakukan hal baik. Jika anak telah melalui proses mengetahui dan menginginkan maka selanjutnya anak akan diajak untuk melakukan hal baik. Mengajak anak melakukan hal baik bisa diawali dari hal-hal yang sederhana yang mereka biasa lakukan di kehidupan sehari-harinya. Misalnya, jika di sekolah guru mengajak anak untuk piket 
membersihkan kelas, jika di rumah orang tua mengajak anak merapikan mainannya dan jika di lingkungan masyarakat anak bisa diajak untuk membersihkan lingkungan disekitar rumah mereka.

Berdasarkan teori ahli, peraturan perundang-undangan dan bahkan peraturan agama telah menjelaskan betapa pentingnya pendidikan karakater itu. Bagi umat Islam, figure nyata dari pendidikan karakter adalah Nabi Muhammad SAW yang diutus oleh Allah SWT sebagai penyempurna akhlak umat Islam. Dalam dunia pendidikan, pendidikan karakter adalah pendidikan yang disengaja dan terencana bukanlah suatu pendidikan yang muncul tanpa disengaja. Negara Indonesia sendiri telah mengatur pendidikan karakter ini di setiap kurikulum pembelajarannya. Terutama kurikulum saat ini yaitu Kurikulum 2013 (K13) atau biasanya disebut dengan Kurikulum Tematik. Tapi lebih dari pada itu, suatu pendidikan karakter bukanlah pendidikan yang hanya semata-mata dilakukan di lingkungan pendidikan saja, tetapi lingkungan keluarga dan masyarakat pun ikut serta dalam memberikan pendidikan karakter tersebut. Melalui sebuah proses mengetahui hal baik, menginginkan hal baik dan disempurnakan dengan melakukan hal baik, karakter seorang anak bisa dibentuk. Pembentukan karakter anak bisa dimulai dari melakukan hal-hal sederhana seperti bermain game. Melalui sebuah permainan yang dimodifikasi dengan ditanamkan karakter-karakter baik didalamnya, diharapkan seorang anak bisa terdidik karakternya dengan baik. Jika karakter anak sudah terdidik dengan baik, maka karakter yang dimunculkan anak nanti pun akan menjadi karakter yang baik pula.

\section{Game Edukasi Berkarakter}

Karakter seorang anak adalah masih suka bergerak, berimajinasi, mengenal lingkungan sekitarnya dan masih selalu penasaran dengan segala sesuatu yang baru ditemuinya. Melalui aktifitas bermain, anak bisa mengembangkan karakter-karakternya tersebut. Aktifitas bermain bisa dilakukan kapan saja dan dimana saja, baik itu di sekolah, di rumah maupun di lingkungan sekitar dengan teman sebayanya. Aktivitas bermain adalah sebuah aktivitas yang dilakukan dan dipilih sendiri tanpa ada paksaan atau tanggung jawab yang harus 
dipenuhi. Tujuan dari aktivitas bermain itu sendiri didapat pada saat bermain itu sendiri. Berbeda dengan aktivitas bekerja. Jika aktivitas bermain tujuannya didapat ketika melakukan aktivitas tersebut, maka aktivitas bekerja tujuannya didapat setelah pekerjaan itu selesai dikerjakan. Aktivitas bermain adalah aktivitas yang selalu ada pada diri anak-anak. Mereka melakukan aktivitas tersebut karena ada keinginan dari dirinya sendiri dan keinginan untuk mengembangkan diri. Bermain adalah suatu aktivitas "bekerja" yang sangat menyita waktu dan seringkali dilakukan oleh anak-anak. Oleh karena itu tidak dapat dipungkiri bahwa "anak dan permainan" tidak dapat dipisahkan dan "dunia anak adalah dunia permainan itu sendiri". ${ }^{11}$ Pada setiap diri anak, terutama anak-anak yang masih kecil, bermain itu adalah belajar. Dengan bermain, anak-anak akan bisa mempelajari berbagai hal disekitar kehidupan sehari-hari mereka.

Kegiatan bermain sudah ada sejak zaman dahulu. Terutama di Indonesia, kegiatan tersebut sudah ada bahkan sebelum zaman kemerdekaan. Bahkan permainan-permainan yang dimainkan pun tidak luput dari penanaman nilai-nilai karakter terutama karakter dalam hal sosial. Hal tersebut dikarenakan banyak permainan yang dimainkan secara bekelompok dan tidak secara individu. Beberapa contoh permainan tradisional yang ada di Indonesia sejak zaman dahulu antara lain: (1) Petak umpet, gobak sodor dan bentengan. Permainan tersebut melatih kecerdasan spasial, mengembangkan motoric kasar, mengatur strategi dan permainan yang bagus untuk olehraga. (2) Congklak, lompat tali, dakon dan bekel. Permainan tersebut bisa mengembangkan kemampuan berhitung dan mengembangkan motorik kasar dan motorik halus. (3) Dodolan/dagangan, gundu, mobil-mobilan dari kulit jeruk dan egrang. Permainan tersebut mengajak anak berinteraksi dengan lingkungan sehingga bisa mengembangkan kecerdasan natural anak. Hal tersebut dikarenakan alat dan bahan yang dibutuhkan dalam bermain adalah bahan-bahan dari alam seperti, buah, pasir, tanah liat,

${ }^{11}$ Abdul Khobir, 'Pengaruh Pendidikan Thaharah Terhadap Sikap Hidup Sehat Santri Pondok Pesantren Di Pekalongan', JURNAL PENELITLAN 7, no. 1 (2013): 96, http://e-journal.stain-pekalongan.ac.id/index.php/Penelitian/article/view/211. 
bambu dan kayu ${ }^{12}$. Sayangnya, seiring perkembangan zaman permainan tradisional tersebut sudah jarang dimainkan. Jika ada yang memainkannya pun tidak banyak terutama di daerah perkotaan. Kalau di daerah pedesaan mungkin masih bisa ditemukan permainanpermainan tersebut. Arus globalisasi dan modernitas lah yang menjadi salah satu faktor tergerusnya permainan tradisional tersebut. Beberapa contoh permainan modern saat ini antara lain playstation dan gamegame ponsel berbasis andoroid dan internet.

Pada saat ini, beragam mainan ditawarkan di pasaran, mulai dari permainan berbasis teknologi modern hingga permainan tradisional dengan menggunakan bahan-bahan konvensional. Permainan tersebut selain menawarkan sebuah hiburan dan kesenangan, juga tidak sedikit yang didalamnya memuat unsur-unsur edukasi. Sebenarnya secara penggunaan, banyak jenis permainan yang bisa disisipkan unsur edukasi tergantung dari user atau penggunanya. Permainan yang bersifat edukasi biasanya banyak dijumpai di kegiatan pembelajaran di sekolah. Para pengajar atau guru biasanya menggunakan permainan tersebut sebagai media dalam menyampaikan materi pembelajaran. Hal tersebut dilakukan untuk memudahkan guru dalam menyampaikan materi kepada siswa. Sehingga siswa diharapkan mampu menerima materi pembelajaran dengan mudah dan menyenangkan.

Adapun permainan edukatif adalah permainan yang memiliki unsur mendidik yang didapatkan dari diri permainan itu sendiri. Unsur tersebut memang ada dan melekat sehingga menjadi bagian dari permainan tersebut. Permainan edukatif akan bisa memberikan dampak positif dan bisa merangsang indera dari si pengguna atau pemain itu sendiri. Indera yang dimaksud adalah indera penglihatan, pendengaran, pengecap (berbicara atau berkomunikasi), keseimbangan kognitif dan afektif, kemampuan daya pikir, kemampuan motorik (keterampilan, gerak dan ketangkasan) dan juga sikap sosial dan spiritual (tata karma, sopan santun, kasih sayang, kejujuran).

Penerapan suatu strategi pembelajaran yang menarik sangatlah dibutuhkan seorang pendidik dalam proses pembelajaran. Hal tersebut

${ }^{12}$ Riva Iva, Koleksi Games Edukatif di Dalam dan Luar Sekolah (Yogyakarta: Flas Books, 2012), 10. 
dilakukan agar kegiatan pembelajaran bisa berjalan efektif, efisien dan juga menyenangkan bagi siswa. Jika guru ingin menggunakan permainan atau game sebagai salah satu strategi pembelajarannya, maka guru harus pintar-pintar memilih mana game yang bisa dikategorikan edukatif dan mana yang tidak. Penentuan nilai edukatif dari sebuah game bisa dianalisis dari manfaat bagi penggunanya. Game yang edukatif adalah game yang bisa menanamkan dan mengembangkan karakter anak, game yang bisa meningkatkan konsentrasi, merangsang daya pikir anak, mengembangkan kemampuan problem solving dan yang paling penting didalamnya tidak mengandung unsur-unsur negative seperti, kekerasan dan pornografi. Berikut beberapa hal yang bisa dijadikan sebagai acuan untuk menilai game memuat nilai edukatif atau tidak: (1) Sesuai sasaran. Bisa mengembangkan kemampuan kognitif, afektif dan psikomotrik anak. (2) Multifungsi. Bisa menggabungkan pengembangan 3 ranah (kognitif, afektif dan psikomotrik). (3) Sesuai dengan tujuan. Game atau permainan yang dimainkan memiliki tujuan yang jelas. (4) Melatih konsep-konsep dasar. Melatih konsep berhitung, menyusun strategi, menghargai pendapat dan konsep lainnya. (5) Merangsang kreativitas. Game yang dimainkan bisa melatih anak berpikir kreatif ${ }^{13}$.

Jika dalam dunia pendidikan, terutama pendidikan Anak Usia Dini, ada salah satu istilah mengenai permainan edukatif yaitu APE (Alat Permainan Edukatif). Alat Permainan Edukatif (APE) adalah segala sesuatu alat yang digunakan untuk bermain yang memuat nilai edukatif (pendidikan) dan bisa mengembangkan segala potensi anak. Permainan tersebut tidak hanya dalam bentuk alat secara konvensional atau tradisional. Tapi juga bisa dikembangkan dengan kemajuan teknologi modern menjadi sebuah aplikasi yang digunakan melalui ponsel maupun computer. Selama proses pembelajaran, peran dari alat permainan edukatif sangatlah penting. Karena alat permainan edukatif adalah sebagai suatu media penyampai pesan dari beberapa sumber kepada penerima pesan. Melalui media alat permainan edukatif yang

${ }^{13}$ Iva, 27. 
digunakan guru dalam menuangkan gagasan dan kreativitasnya, diharapkan dapat mendukung perkembangan anak ${ }^{14}$.

Penggunaan Alat Permainan Edukatif bagi seorang guru biasanya mempunyai beberapa kriteria, diantaranya: (1) Permainan harus menyenangkan terutama bagi anak SD yang mudah bosan. (2) Tingkat kesulitan permainan perlu diperhatikan. Jangan membuat permainan yang terlalu menyulitkan anak. Dan jangan pula terlalu mudah, karena anak akan meremehkan. (3) Permainan mempertimbangkan perkembangan anak. Permainan disetiap jenjang pendidikan anak berbeda, jika anak SD maka gunakan permainan SD jangan anak SMP ataupun sebaliknya. (4) Faktor keselamatan. Buatlah atau gunakan permainan yang tidak membahayakan dan tetap memperhatikan faktor keselamatan anak ${ }^{15}$. Jika APE tersebut dikaitkan dengan penanaman karakter pada anak, tentu hal tersebut ada saling keterkaitannya. Beberapa contoh permainan edukasi yang menggunakan alat yang bisa menanamkan karakter pada anak (biasanya permainan indoor) antara lain: menyusun balok, menyusun lego, menyusun puzzle (menanamkan karakter sabar dan kreatif). Permainan edukasi lain yang lebih mengutamakan gerak fisik dan biasanya dilakukan di luar ruangan (outdoor) antara lain bermain sepak bola, bermain gobak sodor ataupun kegiatan outbond.

Bermain memanglah hal yang menyenangkan terutama bagi anak-anak. Sebagai orang tua tidaklah salah jika ingin memberikan anak sebuah mainan. Tapi alangkah baiknya jika permainan tersebut bernilai edukatif dan bermanfaat bagi perkembangan karakter baik anak. Bukan hanya orang tua, seorang guru atau pendidik juga harus kreatif dalam memilih suatu permainan sebagai strategi pembelajarannya. Sebenarnya tidak perlu biaya mahal untuk membeli permainan edukatif jika kita sebagai orang tua atau guru bisa membuat permainan atau game edukatif itu sendiri. Dari sinilah sebuah skill dan kreatifitas benar-benar

14 Dian Rahma, 'Penggunaan Alat Permainan Edukatif (Ape) Untuk Mendukung Perkembangan Anak Usia 5-6 Tahun Di Paud Al Fikri', Jurnal Pendidikan Dan Pembelajaran 6, no. 10 (n.d.): 3.

${ }^{15}$ Iva, Koleksi Games, 36. 
dituntut dari orang tua atau guru dalam menciptakan sendiri sebuah permaianan edukatif berkarakter untuk anak dan anak didik mereka.

\section{Kesimpulan}

Penanaman pendidikan karakter pada anak sejak dini sangatlah dibutuhkan. Melalui aktifitas yang menyenangkan, pendidikan karakter tersebut bisa ditanamkan. Bermain game atau bermain sebuah permainan adalah sebuah aktifitas yang menyenangkan terutama bagi anak. Melalui aktifitas tersebut, nilai-nilai karakter bisa disisipkan didalamnya. Tapi perlu diperhatikan, dalam bermain sebuah game tidaklah sembarangan. Ada beberapa acuan dan kriteria yang harus diperhatikan dalam pemilihan game itu sendiri. Game yang baik adalah game yang memberikan manfaat bagi penggunanya. Game tersebut bisa merangsang pola pikir anak dan yang paling penting bisa berdampak baik pada perkembangan karakter anak. Jika game yang dimainkan malah justru merusak karakter anak, alangkah baiknya game tersebut tidak diberikan pada anak.

Pada saat ini peradaban semakin maju, teknologi semakin berkembang, pengaruh globalisasi dan modernisasi semakin menunjukkan eksistensinya. Jika pendidikan karakter pada anak tidak semakin dikuatkan, bagaimana masa depan generasi bangsa ini. Pendidikan karakter tidaklah cukup jika hanya diperoleh anak dari sekolah, melainkan harus didukung oleh keluarga dan lingkungan masyarakatnya. Jika segala upaya sudah dilakukan selama proses pendidikan karakter anak, maka perkuatlah pendidikan karakter tersebut dengan pondasi agamanya. Karena dengan pondasi agama yang kuat akan tercipta juga karakter baik yang kuat pada anak itu sendiri. 
Nazhruna: Jurnal Pendidikan Islam

\section{Referensi}

Departemen Agama (Lajnah Pentashihan Mushaf AL-Qur'an). (2007). Al-Qur'anulkarim Terjemah Tafsir Per Kata. Jakarta: Syamil AlQur'an

https://id.m.wikipedia.org/wiki/Globalisasi. Diakses pada, Minggu, 10 Juni 2018, pukul 21.11

https://www.kompasiana.com/radenbaguska/musnahnya-permainantradisional-karena-globalisasi_562f95c24323bd6a09a55efa.

Diakses pada, Minggu,10 Juni 2018, pukul 21.04

Kbbi.web.id. Diakses pada, Minggu, 10 Juni 2018, pukul 21.28

Sujiono, Yuliani. N \& Bambang Sujiono. (2010). Bermain Kreatif Berbasis

Kecerdasan Anak. Jakarta: PT. Indeks

Undang-undang Sistem Pendidikan Nasional.

Fina, Surya Anggraini. Strategi Pembelajaran. Yogyakarta: Ladang Kata, 2017.

Habibah, Syarifah. 'Akhlak Dan Etika Dalam Islam'. Jurnal Pesona Dasar 1, no. 4 (2015).

Husin, Nixson. 'Hadits-Hadits Nabi Saw. Tentang Pembinaan Akhlak'. Jurnal An-Nur 4, no. 1 (2016).

Iva, Riva. Koleksi Games Edukatif di Dalam dan Luar Sekolah. Yogyakarta: Flas Books, 2012.

Khobir, Abdul. 'Pengaruh Pendidikan Thaharah Terhadap Sikap Hidup Sehat Santri Pondok Pesantren Di Pekalongan'. JURNAL PENELITLAN 7, no. 1 (2013). http://e-journal.stainpekalongan.ac.id/index.php/Penelitian/article/view/211.

Lickona, Thomas. Educating for Character: How Our Schools Can Teach Respect and Responsibility. New York: Bantam Books, 2009.

Ma`arif, Muhammad Anas. 'Analisis Strategi Pendidikan Karakter Melalui Hukuman Preventif. Ta'allum: Jurnal Pendidikan Islam 6, no. 1 (6 March 2018): 31-56. https://doi.org/10.21274/taalum.2018.6.1.31-56.

. 'Dhikr and Thinking Integration as Non-Dicotomic Character Education Development | Proceeding International Conference on Islamic Education (Icied)', 16 February 2018. http://conferences.uinmalang.ac.id/index.php/icied/article/view/435. 
Rahma, Dian. 'Penggunaan Alat Permainan Edukatif (Ape) Untuk Mendukung Perkembangan Anak Usia 5-6 Tahun Di Paud Al Fikri'. Jurnal Pendidikan Dan Pembelajaran 6, no. 10 (n.d.).

Trinova, Zulvia. 'Hakikat Belajar Dan Bermain Menyenangkan Bagi Peserta Didik'. Al-Ta Lim Journal 19, no. 3 (2012): 209-215. 